удк $378.14+793.3$

Ірина Ткаченко

Сумський державний педагогічний

університет імені А. С. Макаренка

ORCID ID 0000-0002-7612-1082

DOI 10.24139/2312-5993/2019.07/294-303

\title{
ОЗДОРОВЧЕ ЗНАЧЕННЯ ПАРТЕРНОЇ ГІМНАСТИКИ ДЛЯ СТУДЕНТІВ-ХОРЕОГРАФІВ
}

У статті висвітлено оздоровче значення партерної гімнастики для студентівхореографів. На основі використання загальнонаукових та конкретнонаукових методів дослідження схарактеризовано партерну гімнастику як самостійний комплекс вправ, які виконуються на підлозі в різних положеннях з метою зміцнення, розвитку опорнорухового та розтяжки м'язового апарату майбутніх фрахівців хореографрів. Схарактеризовано історичні закономірності партерної гімнастики. Доведено вплив партерної гімнастики на фізичний розвиток студентів-хореографів та подано класифрікацію базових вправ. Розкрито оздоровчий потенціал занять партерною гімнастикою на психічне, духовне й соціальне здоров'я майбутніх фрахівців хореографії. Виокремлено основні оздоровчі принципи партерної гімнастики.

Ключові слова: партер, гімнастика, партерна гімнастика, хореографія, студенти-хореографи, майбутні фахівці хореографії, фізичне здоров'я, вправа, оздоровчі принципи.

Постановка проблеми. Проблема збереження здоров'я студентської молоді останнім часом стає актуальною, адже невпинно зростає темп життя, змінюються вимоги щодо навчальної діяльності сучасного фахівця. Під таким кутом зору фокусується увага на забезпеченні вищої хореографічної освіти без втрат здоров'я студентів-хореографів. Щоденні фізичні навантаження, психологічна втома в цілому накладають відбиток на весь організм майбутніх фахівців хореографів. Вирішенням цієї проблеми $€$ систематичні заняття партерною гімнастикою, яка передбачає максимальне збереження та зміцнення здоров'я студентів-хореографів, а також розвиток їх фізичних якостей відповідно до фізіологічних особливостей організму. Більш того, партерна гімнастика забезпечує виховання фізичної культури особистості.

Аналіз актуальних досліджень. Вагоме значення для осмислення досліджуваного феномену мають праці вітчизняних дослідників, які порушують проблеми хореографічної освіти в Україні (Л. Андрощук, Т. Благова, С. Куценко, Г. Ніколаї, Т. Повалій та ін.). Значний інтерес у контексті означеної проблеми становлять наукові праці вчених, які висвітлюють такі питання, як: базові засоби гімнастики, акробатики та їх значення в підготовці танцюристів (А. Довгановська, В. Сосіна); особливості викладання стретчингу (Т. Драч); вплив ритмічної гімнастики та аеробіки на розвиток особистості (В. Сіткар) тощо. 
Набувають фундаментальності дослідження з питань партерного тренажу, ритмічної гімнастики, партерної гімнастики, що порушуються в роботах Т. Калашник, В. Сосіної, О. Шевченко та ін. Водночас аналіз наукової думки надає підстави стверджувати, що оздоровче значення партерної гімнастики для студентів-хореографів не були предметом цілісного дослідження.

Мета статті - висвітлити оздоровче значення партерної гімнастики для студентів-хореографів.

Методи дослідження. Для реалізації й досягнення поставленої мети нами було використано комплекс методів, зокрема загальнонаукові - аналіз, синтез, узагальнення, систематизація, які застосовувалися для з'ясування стану розробленості проблеми, характеристики партерної гімнастики загалом. Крім того, застосовано комплекс конкретнонаукових методів: термінологічний аналіз та інтерпретація, що використовувалися при визначенні базового поняття нашої роботи; історико-генетичний, який було використано з метою висвітлення історичних закономірностей партерної гімнастики.

Виклад основного матеріалу. На основі аналізу й систематизації джерелознавчої літератури нами було встановлено, що термін «партерна гімнастика» (часто зустрічається «партерний екзерсис») утвердився нещодавно, що було зумовлено появою та розвитком нетрадиційних видів гімнастики. Зазначимо, що слово «партер» походить від французького parterre, від par - «по» + terre - «земля». Натомість, гімнастика $\epsilon$ сукупністю фізичних вправ, спеціально підібраних і орієнтованих на загальний розвиток організму людини. Водночас під дефініцією «партерна гімнастика» розуміємо виконання різного роду вправ в положенні лежачи, сидячи, на боці, з різних упорів тощо (Калашник, 2018).

Кандидат педагогічних наук, професор, майстер спорту з художньої гімнастики В. Сосіна під партерною гімнастикою розуміє вправи на підлозі в різних позах, сидячи, лежачи на животі та спині, які спрямовані на розвиток гнучкості в суглобах, на розтяжку всіх м'язів тіла, їх зміцнення (Сосіна, 2013, с. 4).

На основі історико-генетичного аналізу нами було встановлено, що партерна гімнастика була відома ще в другій половині XX ст. і мала назву «балетна гімнастика». Означена система занять була створена представником російської балетної школи Борисом Князевим і заснована на основних рухах класичного екзерсису. Система партерної гімнастики Б. Князева набула широкої популярності в створеній ним балетній школі в Женеві, а також стала основою для багатьох балетних шкіл Європи. Установлено, що за системою Б. Князева в Англії було видано книгу Дж. Северна «Школа танців без станка. Вчить вашу дитину мистецтву балету на основі нової системи Бориса Князева». В Україну партерна гімнастика Б. Князева прийшла в післявоєнні роки. Звернення педагогів-хореографів до нової системи відбувається з $60-x$ років минулого століття (Вавилін). 
Принагідно зазначимо, що на сучасному етапі розвитку суспільства хореографічне мистецтво характеризується технічною складністю та поєднує в собі різні види мистецтва і спорту. Погоджуючись із твердженням В. Сисоєвої, наголосимо, що не тільки танець, а й балет в цілому все більше наближається до спорту (Сосіна, 2019, с. 81). Під таким кутом зору, до освітнього процесу Сумського державного педагогічного університету імені А.С. Макаренка, зокрема кафедри хореографії та музично-інструментального виконавства було запроваджено вивчення навчальної дисципліни «Гімнастика та віртуозні рухи», яка передбачає опанування також партерної гімнастики.

Зауважимо, що кістковий корсет та м'язи студентів-хореографів завжди повинні бути не тільки в тонусі, гнучкими й підтягнутими, але і сильними, для того, щоб здійснювати хореографічні па та різні фізичні навантаження. Слабка мускулатура не може забезпечити достатню функціональність всіх частин тіла. Переносячи все навантаження на суглоби і зв'язки, починає виникати біль у спині, руках, ногах тощо. Вирішенням означеної проблеми є саме заняття партерною гімнастикою (Ткаченко, 2018, с. 38).

Нами було встановлено, що партерна гімнастика $є$ фундаментом для розвитку рухових функцій, зокрема підйому та виворотності ніг, гнучкості корпусу, граціозного кроку, високого стрибка. Більш того, для студентівхореографів партерна гімнастика $є$ одним із етапів досконального оволодіння традиційного класичного і народного екзерсису біля станка, який потребує високого фізичного напруження. Заняття партерною гімнастикою дозволяють набути навичок рівного і підтягнутого корпусу, надають уявлення студентамхореографам про роботу всіх м'язів опорно-рухового апарату, а саме м'язів спини, ніг, рук, шиї тощо. Зазначимо, що вправи партерної гімнастики розтягують та зміцнюють ахіллове сухожилля, а також допомагають розвинути витягнутість колінного та гомілковостопного суглобів. Вправи партерної гімнастики прекрасно розвивають м'язи живота, виворітність ніг від тазостегнового суглобу до гомілковостопного, гармонійно формують та збільшують м'язову масу, амплітуду кроку, вирівнюють точність координації руху. При цьому поставлена мета відбувається без навантаження на хребет, без напруги всього тіла.

Принагідно зазначимо, що всі вправи партерної гімнастики виконуються в повільному темпі, оскільки швидкий темп не сприяє глибокому «диханню» м'язів. Партерна гімнастика в хореографії виключає зовнішню механічну дію. Студенти-хореографи власними зусиллями мають розвивати гнучкість, виворітність тощо. Аналіз наукових джерел та їх систематизація дозволяють стверджувати, що вправи партерної гімнастики, вихідне положення яких лежачи та сидячи, зменшують вертикальну опору на ноги та хребет учасника освітнього процесу. 
Водночас, загальне фізичне навантаження у вправах партерної гімнастики досить високе (Якушева, 2018).

На основі порівняльно-зіставного аналізу нами було встановлено, що при виконанні вправ партерної гімнастики м'язи студентів-хореографів працюють в іншому режимі та приймають на себе дещо інакше навантаження, ніж у вправах, які передбачають виконання в положенні стоячи. На нашу думку, партерна гімнастика $€$ важливою для повноцінного та вдалого засвоєння класичного, народного, сучасного та інших танцювальних напрямів. Так, щоденні грамотні заняття партерною гімнастикою дозволяють більш краще розвинути природні фізичні дані танцівників та допомагають в успішному самостійному набутті таких якостей, як легкість і сила ніг, виворітність, підйом ступні, швидкість, гнучкість, висота стрибка тощо (Ткаченко, 2018, с. 34).

Нами було встановлено, що вправи партерної гімнастики виникли в зв'язку із задоволенням життєво необхідних потреб людини. Тому, деякі з них характеризують рухи, які було запозичено з бойової, трудової та побутової людської діяльності. Розвиток суспільства й наукових знань про систему фізичного виховання та навчання зумовили виникнення абстрактних рухів, які характеризують собою нескладні рухи, що виокремлено з цілісних рухових дій. Вони складають переважну більшість вправ партерної гімнастики.

Вважаємо за необхідне наголосити, що в роботі зі студентамихореографами доцільно використовувати спеціальні комплекси вправ партерної гімнастики, які позитивно впливають на фізичне, психічне, духовне, соціальне здоров'я майбутніх фахівців та безпосередньо спрямовані на розвиток опорно-рухового і м'язового апарату студентів. Так, особливу увагу доцільно звертати на такі базові вправи партерної гімнастики, як:

- вправи на розвиток рухливості, укріплення зв'язок стопи, гомілковостопного суглобу;

- вправи на розвиток виворітності та рухливості тазостегнового й колінного суглобів;

- вправи на розвиток амплітуди танцювального кроку;

- вправи на розвиток еластичності м'язів стегна;

- вправи на розвиток гнучкості та зміцнення м'язів спини;

- вправи на укріплення м'язів черевного пресу;

- вправи на розвиток рухливості плечових суглобів.

Так, до вправ на розвиток рухливості, укріплення зв'язок стопи, гомілковостопного суглобу належать: зміцнення стоп, зведення стоп, зведення стоп 3 тягою, релєве 3 м'ячем, згинання стопи в гомілковостопному суглобі, скорочення стоп, кругові оберти, видавлювання підйому тощо. 
До вправ на розвиток гнучкості та зміцнення м'язів спини й укріплення черевного пресу належать: нейтральне положення, корсет для хребта, відведення ніг лежачи, ізометричне скручування, змійка, кішка, складочка, зворотна складочка, кільце, корзинка, перекати, годинник, махи, підйом грудної клітки, підйом ніг тощо. Розтяжка верхньої та бокової частини стегна, розтяжка широкої фасції стегна, жабка, згинання ніг у тазостегновому суглобі і т. Д. забезпечують розвиток виворітності та рухливості тазостегнового й колінного суглобів.

Наголосимо, що методику виконання вище зазначених вправ подано нами в розробленому навчальному посібнику «Естетична гімнастика в хореографії: історія, теорія, практика» (Ткаченко, 2018).

Можемо стверджувати, що заняття партерною гімнастикою покращують трофіки між хребцевих структур, збільшують рухливість суглобів, зміцнюють та розвивають всі групи м'язів, а також сприяють нормалізації роботи серцево-судинної та дихальної системи. Так, першочерговими завданнями партерної гімнастики є: розвиток сили м'язів, зміцнення суглобів і підвищення їх рухливості; зміцнення опорно-рухового апарату; розвиток витривалості й постановка дихання; вироблення навичок високої рухової культури (Айунц, 2008, с. 17).

А. Вавилін доводить, що комплекс вправ партерної гімнастики (у положеннях лежачи, сидячи, на колінах) найбільш стабільно впливають на систему кровообігу, де частота серцевих скорочень не перевищує 130-140 ударів за хвилину, тобто не виходить за межі зони аероба (одна з основних пульсових зон, що вимагає тренування при 70-80 \% від чСС людини). Дослідник відзначає, що заняття повинні нести оздоровчу спрямованість і водночас не шкодили організму студентів. Вибір серій вправ і темпу рухів мають здійснюватися так, щоб тренування несло характер аероба (зі збільшенням частоти серцевих скорочень в межах 130-150 ударів за хвилину). У результаті занять відбувається поліпшення не тільки функцій опорно-рухового апарату, зокрема збільшення рухливості в суглобах, сили м'язів, гнучкості, а й підвищення рівня загальної витривалості (Вавилін).

Особливістю занять із партерної гімнастики $€$ те, що інтенсивність виконання вправ та темп рухів задаються ритмом музичного супроводу. Так, доцільно наголосити, що партерна гімнастика включає в себе комплекс вправ, які передбачають біг та стрибки (застосовуються з метою інтенсивного розігріву) і впливають на серцево-судинну систему, натомість, присідання і нахили - на руховий апарат, а вправи на розслаблення - на центральну нервову систему. Водночас, вправи, які виконуються безпосередньо на партері, розвивають рухливість, еластичність, гнучкість у суглобах та м'язах і одночасно їх силу.

Відзначимо, що вправи партерної гімнастики становлять собою злиті комбінації, які мають танцювальний характер та невід'ємно пов'язані $з$ 
музикою й відзначаються композиційною цілісністю та динамічністю. Особлива виразність і якість рухів залежать саме від вибору музичного матеріал, що супроводжує заняття для студентів-хореографів. Музичний супровід позитивно впливає на емоційний стан студентів, розвиток координації рухів, музичної пам'яті, слуху. Добір музичного матеріалу визначається характером кожної вправи, а також рівнем естетичної підготовленості студентівхореографів. Наголосимо, що взаємодія музики й руху неодноразово досліджувалася в психологічній та педагогічній галузях. Так, Н. Ветлугіна доводить, що за одночасним виконанням, між музикою і рухом установлюються дуже тісні взаємозв'язки, які об'єднані поетичним змістом (Ветлугіна, 1978).

Висвітлюючи оздоровче значення партерної гімнастики для студентів-хореографів, зокрема ї̈ вплив на фізичний розвиток майбутніх фахівців, вважаємо за необхідне також охарактеризувати позитивний ефект занять на психічне та соціальне здоров'я. Так, психічне здоров'я студентів-хореографів відзначається високим рівнем психічних процесів, наявністю розумових якостей, здатністю керувати власними емоціями. Психічно здорові студенти вірять у власні сили, проявляють самостійність, організованість, поважно ставляться до інших людей. Тому велике значення для психічного здоров'я студентів-хореографів має партерна гімнастика, яка крім вище зазначених комплексів вправ передбачає вправи на релаксацію. Останні забезпечують переключення уваги та приводять організм у цілковитий відпочинок.

Водночас, під впливом занять партерною гімнастикою спостерігаємо зміни щодо духовного та соціального здоров'я студентів-хореографів. Зазначимо, що духовною складовою здоров'я людини $є$ віра в духовці цінності, зокрема добро, любов тощо, а також визначення себе як частини природи та суспільства. Духовне здоров'я студентів-хореографів відзначається моральністю й відповідальністю, визначає світосприйняття, чистоту намірів, думок та моральних учинків. Одним із джерел духовного життя майбутніх фахівців хореографії $€$ саме вправи партерної гімнастика, які передбачають і елементи класичного екзерсису. Як результат, студенти-хореографи звертаються до традицій танцювального мистецтва, знайомляться з історією, музикою, елементами вітчизняної та світової хореографічної спадщини.

Натомість, під соціальним здоров'ям ми розуміємо вміння спілкуватися з іншими людьми в будь-яких життєвих ситуаціях. Соціально здорові студенти швидко адаптуються до нових суспільних умов, соціальних вимог, охоче спілкуються та знаходять рішення у різноманітних конфліктних ситуаціях, що можуть виникати в процесі навчальної діяльності.

Тому, розглядаючи позитивні сторони партерної гімнастики та ії оздоровчий потенціал на студентів-хореографів зазначимо, що кожна вправа має надавати профілактичний та відновлювальний вплив на весь організм і, водночас, підтримувати стан здоров'я та попереджати 
захворювання в майбутніх фахівців хореографії. Тому, доцільно наголосити на основних оздоровчих принципах партерної гімнастики, а саме:

- єдність середовища і організму (соціального й біологічного);

- цілісність організму (єдність фізичного та психічного);

- єдність форми та функції.

Так, принцип єдності середовища і організму (соціального й біологічного) полягає в тому, що від народження кожна людина має різну анатомічну будову, структуру кісткового корсету та м'язового апарату. Однією з біологічних особливостей людини $€$ висока пластичність, що сприяє більш легкому освоєнню вправ партерної гімнастики. Натомість, цілеспрямовані систематичні заняття забезпечують максимальне набуття таких фізичних якостей, як гнучкість, сила, спритність, витривалість, що забезпечують ефективність виконання вправ партерної гімнастики.

Підкреслимо, що принцип єдності фізичного і психічного здоров'я відзначається тим, що м'язова робота істотно впливає на розвиток організму студентів-хореографів, забезпечує підвищення життєво необхідної енергії. Вправи партерної гімнастики покращують сон, настрій, працездатність. Рухова активність у цілому впливає і на вищу нервову систему майбутніх фахівців хореографії. Під впливом систематичних занять партерною гімнастикою покращується врівноваженість нервових процесів та рухливість кістково-суглобового апарату. Крім того, нервова система здатна краще та швидше пристосовуватися до нових видів діяльності. Наголосимо, що розвиток фізичних якостей студентів-хореографів та їх рухові навички позначаються i на інтелектуальному зростанні. Таким чином, головні компоненти здоров'я, зокрема фізичне, психічне, духовне становлять єдину цілісну систему, а не існують окремо. Натомість, принцип єдності форми та функції полягає в тому, що всі вправи партерної гімнастики впливають на весь організм студентів-хореографів. Одночасно зі зміцненням опорно-рухового та м'язового апарату, вправи партерної гімнастики забезпечують кістковом'язовий корсет еластичністю зв'язок та суглобів, пластичністю тіла, нормалізують роботу органів дихання та серцево-судинної системи тощо.

Зазначимо, що методика викладання партерної гімнастики для студентів-хореографів передбачає використання і загальнопедагогічних принципів, серед яких ми виділяємо такі, як: наочності, доступності, системності, індивідуального підходу, комбінаторності. Так, принцип наочності передбачає вивчення студентами рухів, які демонструє викладач (зорові відчуття). Показ різноманітних вправ та комбінацій має супроводжуватися поясненням, що допомагає студентам-хореографам правильно виконувати вправи.

Водночас, принцип доступності $€$ результатом виконання вправ від простих і легких до більш складних, що потребують максимальних зусиль. Урахування стану студентів-хореографів, рівня підготовки забезпечує 
принцип індивідуального підходу. Важливим під час занять партерною гімнастикою $є$ використання вправ на зміцнення різних груп м'язів (принцип комбінаторності). Так, одна вправа має включати декілька рухів, що відповідають за різні навантаження на організм студентів (Якушева. 2018).

Отже, систематичні заняття партерною гімнастикою успішно вирішую проблему всебічного фізичного розвитку студентів-хореографів та вдосконалюють їх рухові можливості. Крім того, забезпечують збереження психічного, духовного та соціального здоров'я. Комплекс вправ партерної гімнастики позитивно впливає на весь ланцюг опорно-рухового апарату, на всі групи м'язів та системи органів. Партерна гімнастика забезпечує вдосконалення серцево-судинної, дихальної та нервової систем, а також тренує органи рівноваги (вестибулярний апарат) тощо. Саме партерна гімнастика представляє собою систему спеціально підібраних вправ, які націлені на максимальне збереження здоров'я майбутніх фахівців хореографії.

Висновки та перспективи подальших наукових розвідок. Термінологічний аналіз та інтерпретація наукової думки дозволили схарактеризувати партерну гімнастику для студентів-хореографів як самостійний комплекс вправ, які виконуються на підлозі в різних положеннях (на спині, животі, боці) з метою зміцнення й розвитку опорнорухового та розтяжки м'язового апарату майбутніх фахівців.

Установлено, що вправи партерної гімнастики в цілому позитивно впливають на фізичне, психічне та духовне здоров'я студентів-хореографів. Партерна гімнастика сприяє вдосконаленню й зміцненню опорно-рухового та м'язового апарату, підвищенню гнучкості суглобів та поліпшенню еластичності зв'язок. Саме вправи партерної гімнастики забезпечують нормалізацію роботи серцево-судинної та дихальної системи студентів-хореографів.

Доведено, що партерна гімнастика для студентів-хореографів передбачає базові вправи, що класифікуються як: вправи на розвиток рухливості, укріплення зв'язок стопи, гомілковостопного суглобу, вправи на розвиток виворітності та рухливості тазостегнового й колінного суглобів, вправи на розвиток амплітуди танцювального кроку, вправи на розвиток еластичності м'язів стегна, вправи на розвиток гнучкості та зміцнення м'язів спини, вправи на укріплення м'язів черевного пресу, а також вправи на розвиток рухливості плечових суглобів.

Установлено, що викладання партерної гімнастики для студентівхореографів реалізується за допомогою оздоровчих (єдність середовища і організму (соціального й біологічного), цілісність організму (єдність фізичного та психічного), єдність форми й функції) та загальнопедагогічних (наочності, доступності, системності, індивідуального підходу, комбінаторності) принципів.

Проведене дослідження не вичерпує всіх аспектів проблеми викладання партерної гімнастики для студентів-хореографів і засвідчує 
необхідність їі подальшого розроблення за такими перспективними напрямами, як значення стретчингу в підготовці фахівців-хореографів, вплив базових елементів гімнастики на фізичний розвиток танцівників.

\section{ЛITEPATУPA}

Айунц, Г. (2008). Гімнастика. Методичні матеріали до теоретичної підготовки студентів фракультету фізичного виховання і спорту. Житомир (Aiunts, H. (2008). Gymnastics. Methodological materials for theoretical training of students of the Faculty of Physical Education and Sports. Zhytomyr).

Вавилін, А. Партерна гімнастика як інструмент формування здоров'язберігаючої компетентності юного танцюриста. Режим доступу: https://arabesknbdu.at.ua/index/parterna gimnastika/0-15. (Vavylin, A. Ground gymnastics as a tool for forming a young dancer's health-saving competence. Retrieved from: https://arabesknbdu.at.ua/index/parterna gymnastika/0-15).

Ветлугіна, Н. (1978). Музичний розвиток дитини. Київ (Vetluhina, N. (1978). Musical development of the child. Kyiv).

Калашник, Т. (2018). Партерна гімнастика. Донецьк (Kalashnyk, T. (2018). Ground gymnastics. Donetsk).

Сосіна, В. (2013). Методика проведення тренажу і партерного тренажу. Львів (Sosina, V. (2013). M ethods of training and ground training. Lviv).

Сосіна, В. (2019). Базові засоби гімнастики та акробатики та їх значення у підготовці танцюристів. Кінезіологія танцю та техніко-естетичних видів спорту, 81-89 (Sosina, V. (2019). Basic gymnastics and acrobatics and their importance in the training of dancers. Kinesiology of Dance and Techno-Aesthetic Sports, 81-89).

Ткаченко, І. (2018). Естетична гімнастика в хореографії: історія, теорія, практика. Суми: ФОП «Цьома С. П.» (Tkachenko, І. (2018). Aesthetic gymnastics in choreography: history, theory, practice. Sumy).

Якушева, В. (2018). Партерна гімнастика. Вправи на виворітність. Режим доступу: https://vseosvita.ua/library/urok-z-horeografii-dla-ucniv-4-a-klasu-tema-parternagimnastika-vpravi-na-vivorotnist-98180.html (Yakusheva, V. (2018). Ground gymnastics. Quirky exercises. Retrieved from: https://vseosvita.ua/library/urok-zhoreografii-dla-ucniv-4-a-class-theme-partner-gymnastics-of-vivrotnist-98180.html.).

\section{PEЗЮME}

Ткаченко Ирина. Оздоровительное значение партерной гимнастики для студентов-хореографов.

В статье отражено оздоровительное значение партерной гимнастики для студентов-хореографов. На основе использования общенаучных и конкретнонаучных методов исследования охарактеризована партерная гимнастика как самостоятельный комплекс упражнений, которые выполняются на полу в разных положениях с целью укрепления, развития опорно-двигательного и растяжки мышечного аппарата будущих специалистов хореографов. Охарактеризованы исторические закономерности партерной гимнастики. Доказано влияние партерной гимнастики на фризическое развитие студентов-хореографов и подана классификация базовых упражнений. Раскрыт оздоровительный потенциал занятий партерной гимнастикой на психическое, духовное и социальное здоровье будущих специалистов хореографии. Выделены основные оздоровительные принципы партерной гимнастики. 
Ключевые слова: партер, гимнастика, партерная гимнастика, хореография, студенты-хореографы, будущие специалисты хореографии, физическое здоровье, упражнение, оздоровительные принципы.

\section{SUMMARY}

Tkachenko Irina Health value of ground gymnastics for students-choreographers.

The article highlights the health value of ground gymnastics for studentschoreographerb. In order to achieve this goal we used a set of methods, including general scientific - analysis, synthesis, generalization, systematization, which were used to determine the state of development of the problem, the characteristics of ground gymnastics in general. In addition, a set of specific scientific methods was applied: terminological analysis and interpretation, which were used in defining the basic concept of our work; historical-genetic, which was used to cover historical patterns of ground gymnastics.

Based on the use of general and specific scientific research methods, ground gymnastics is characterized as an independent set of exercises that are performed on the floor in different positions in order to strengthen, develop the musculoskeletal and stretching muscles of future specialists of choreographers. The historical patterns of ground gymnastics are characterized. The influence of ground gymnastics on the physical development of students-choreographers has been proved, which involves improving and strengthening the musculoskeletal and muscular apparatus, increasing the flexibility of joints and improving the elasticity of ligaments, as well as normalizing the work of the cardiovascular and respiratory systems of students-choreographers.

The classification of basic exercises of the ground gymnastics is given. These exercises include: exercises for the development of mobility, strengthening of the ligament of the foot, ankle joint, exercises for the development of the inversion and mobility of the hip and knee joints, exercises for the development of the amplitude of the dance step, exercises of the step muscle, exercise, exercises for the development of flexibility and strengthening of the muscles of the back, exercises for strengthening the muscles of the abdominal press, as well as exercises for the development of mobility of the shoulder joints. The health potential of ground gymnastics for the mental, spiritual and social health of future specialists of choreography is revealed.

The basic health principles of ground gymnastics, in particular the principle of unity of environment and organism (social and biological), the principle of the integrity of the organism (unity of physical and mental), the principle of unity of form and function, are distinguished.

Key words ground floor, gymnastics, ground gymnastics, choreography, studentchoreographers, future specialists in choreography, physical health, exercise, health principles. 